\title{
Motivational factors affecting online learning by Japanese MBA students
}

\author{
Hisayo Kikuchi \\ Nihon University
}

In Japan, Internet based learning is still at an early stage. However, adult learners in Japanese society expect the development of flexible e-learning programs. This case study examines motivational factors affecting online learning in a Japanese and Australian MBA program, using observations, interviews and a questionnaire survey. The data were investigated from motivational categories of the ARCS model (an acronym from Attention, Relevance, Confidence and Satisfaction) and influence of e-learners' learning environment, by comparing two e-learning experience stages, beginning and final. The analyses revealed that whereas the e-learners at the beginning stage were curious about e-learning, required encouragement in individual learning situations, and set goals individually, the learners with about two years e-learning experience were motivated by interdependence, flexibility and sharing the rewards with family. The study also showed motivation of adult e-learners was individually different, but was positively influenced by online collaborative interaction, in particular with peers and in group activities. Interaction in e-learning settings went beyond social activities and the simple exchange of information. This article concludes with some suggestions for improving the design of e-learning programs for Japanese students.

\section{Introduction}

The Internet has opened opportunities for working adult learners to pursue their further studies in a more flexible way by interacting with content topics, teachers and other e-learners synchronously and asynchronously. However, in Japan Internet based learning or e-learning is still at an early stage of development. According to a recent survey by the National Institute of Multimedia Education (NIME, 2006), 16.5\% of university units of study have applied an e-learning mode to credits, and only $2.2 \%$ to internationally transferable credits. According to this survey, the inhibiting factors are the burden of preparation for classes $(66.9 \%)$, and concern with cost effectiveness (32.3\%). Further, there are concerns over quality assurance, students' demotivation, alienation between teacher and elearner, and the digital divide. This low adoption of e-learning is also 
attributable to Japanese culture. Education in Japan values synchronous and face to face modes over asynchronous interaction more than in many other countries (Yoshida \& Taguchi, 2005). 53.7\% of the universities care about lack of promotion for humanistic, character building education in elearning environments (Yoshida \& Taguchi, 2005). Japanese are also anxious about reliability and security of e-learning.

Despite this slow adoption of e-learning in Japan, the number of adult learners has been increasing rapidly. MEXT (2006) showed $18.6 \%$ at graduate schools and $43.5 \%$ at professional graduate schools are adult learners who have a job. The development of flexible and learner centred elearning programs for adult learners is expected in Japan.

The findings from studies on e-learning in other countries are mostly positive. For example, such studies report that students' satisfaction is high (e.g. Allen et al., 2004; National Center for Education Statistics, 2005) and a learner centred, collaborative knowledge building community is possible in an e-learning environment (e.g. Li, 2004; Luca \& McLoughlin, 2004). Several studies show that e-learning can be more effective than classroom settings when it is designed appropriately for target learners (e.g. Becker, 2002; Chou \& Liu, 2005; Scheuermann, 2003; Sitzmann \& Wisher, 2005).

There have been many studies on adult e-learners' motivation in other countries. For example, Kim et al. (2004) conducted a case study on elearners' motivation in an online MBA program in the US and revealed that both the e-learners and the faculty indicated a high level of motivation for completing the program due to their clear goals, flexibility and convenience. Stepheson (2003) studied the learning experiences of adult elearners in Denmark, France, Germany, Greece, Hungary, Italy, Romania, Spain and UK, based on lengthy, semi-structured interviews and data analysed on a European cross sector basis, finding that key motivators were to gain new skills and knowledge relevant to work, personal development, and future careers. This study suggested e-learning succeeds where it is cutomised, organised by the user, relevant to the user's everyday work, supported by the employer, linked to just in time specialist material and fully supported within a healthy learning milieu. Bird and Morgan (2003) investigated the motivational factors of adult e-learners in Australia and found that adult e-learners are concerned with many issues, including family support, ability, fear of failure, and financial problems, and suggested that educators need to provide clear pre-information and proper advice for e-learners prior to their start. Lim (2004) compared e-learner motivation in Korea and the US, and found that American e-learners showed significantly higher motivation scores for unit relevancy, content interest, reinforcement and self efficacy than Korean e-learners, and suggested that educators realise that each culture's achievement relevant 
beliefs, goals and values, and also individual level variables, influence each e-learner's motivation.

In contrast, little research has been done into motivational factors affecting Japanese e-learners. With the increase in the number of adult e-learners in Japan, there is a need for understanding Japanese e-learners and their external environments, in order to make effective use of e-learning. The purposes of this study are to examine factors affecting motivation of working adult e-learners in Japan, and to provide some suggestions for improving the design of adult Japanese e-learning programs. More specifically, this study attempts to answer the following three questions:

- What differences and similarities in motivation factors, in both internal and external categories, exist between novices and successful e-learners?

- How are general characteristics of Japanese students related to elearning experience and motivation?

- What are elements that enhance or interfere with e-learners' motivation in this MBA program?

\section{Methodology}

\section{Setting}

This study analysed an online MBA (Master of Business Administration) program named the Bond-BBT MBA program in Japan. In 2001 a for profit company named Business Breakthrough Inc. (BBT Inc.) started this online MBA program by affiliating with Bond University in Queensland. This program, the first totally online MBA program in Japan, offers the same accredited MBA degree as the one offered on campus at Bond University under the approval of Australian University Quality Agency (AUQA). This program provides about half of its units of study in English and the others in Japanese. Whilst English units are created by the Bond University, focusing on theory in business and administration, Japanese units are developed by BBT Inc., emphasising practical business cases. The duration of this program is two years, and students are allowed to expand their study period to a maximum of five years. In July 2006, 486 e-learners are learning in this program and graduates numbered 205.

The units of study for the Bond-BBT MBA program are delivered through TV lectures (satellite TV and Video On Demand), Blackboard (an online learning management system) and eight-day, face to face campus study tours at the end of the first and second years. Both English and Japanese units use an English version of Blackboard 6 adaptable to multilingual contexts, and all content, including online discussion and emails, follows the unit's language, either English or Japanese. AirCampus, developed by BBT Inc., enables offline synchronisation so that users can have access even 
when on trains or airplanes. Each unit has around 40 to 100 e-learners under one professor and one to four teaching assistants, and assigns to groups of four or five members, weekly online discussions, four to six online virtual classes, ten quizzes, and a final examination. One unit takes 6 to 16 weeks, depending on the unit content. Unlike any other MBA programs, this program requires neither the TOEFL (Test of English as a Foreign Language) (undated) nor the GMAT (Graduate Management Admissions Test) for admittance. However, before participating in the first study tour on the Bond campus, the e-learners are required to attain 570 or equivalent in the TOEFL PBT (Paper Based Test), or to pass a 12-week English supplemental unit of study. There are three entry points a year and each has around 40 new e-learners. Currently, the completion rate for this MBA program is about $50 \%$ within two years; however, because around half of the e-learners extend their graduation by three months to two years, the rate of e-learners who completely quit this program is under $15 \%$.

\section{Participants}

About 99\% in the Bond-BBT MBA e-learning program are working adults. Most have more than 10 years of working experience in corporations. The average age is 36 , and the range is 27 to 62 years. Almost all have graduated from universities, $13 \%$ with a doctor's or master's degree in another field such as technology or accounting. About $91 \%$ are males and $9 \%$ are females, $69 \%$ live in the Kanto area, around Tokyo, and 5\% are on business trips in other countries including Australia, America, China, Germany, Indonesia, Korea, Russia, Thailand, United Arab Emirates, and Vietnam. Over $70 \%$ live with their own family with or without children.

For the purpose of this study, two groups were selected in May 2005, named as Group A and Group B. Group A consisted of 72 e-learners who had begun the program and just completed only one unit, in Japanese. Group B consisted of 102 e-learners who had almost completed the program, requiring only one or two more units to graduate. Thus, participants of Group A were novices whereas those of Group B were experienced e-learners. All participants, a total of 174, were self financed. A total of 138 out of 174 e-learners replied to the survey, 68 from Group A and 70 from Group B. Given the high completion rate of this MBA program, the novice e-learners of Group A will also be considered as potentially successful e-learners.

Table 1: Participants in the study

\begin{tabular}{|l|c|c|}
\hline & Group A & Group B \\
\hline Survey sent to & 72 & 102 \\
\hline Replies from & 68 & 70 \\
\hline Response rate & $94.4 \%$ & $68.6 \%$ \\
\hline
\end{tabular}


The response rate in Group B was rather low, possibly due to their deadlines for the final project required before graduation.

\section{Procedure}

The author worked for this MBA program as a manager and program coordinator for four years since 2001 when this program opened. This position offered her the opportunity to collect information which would not have been obtainable under other circumstances.

First, observation data had been collected through direct observations of elearners' everyday online activities and the on campus tours since 2001. Observation data were recorded and reviewed by other staff members of the program. In addition to the author's observations, informal conversational interviews were held with 27 e-learners, 11 selected from Group A and 16 from Group B. Conducted on the 21 May 2005 over dinner, the interviewing required several hours and was designed to elicit from individual students factors motivating them to continue or hindering them from the online study.

Based on the data collected from the observations and the interviews, focus group research was conducted in June 2005. Focus group research can help to develop question items through organised discussion with a small group of involved persons (Gibbs, 1997). The focus group consisting of the author and three other staff members discussed and analysed the data, while eliciting a multiplicity of views. Through this discussion, motivational factors salient for our e-learners were classified into 26 items.

Using these 26 motivational items delineated by the focus group findings, a pilot survey using a five-point Likert type scale ( 1 for 'strongly disagree', 2 'disagree', 3 'neutral', 4 'agree' and 5 'strongly agree') was conducted in Japanese from 9 to 15 July 2005. This survey contained an open question so that the participants were able to write freely about their motivation factors. The participants were 6 novice e-learners and 11 successful elearners. As the result of this pilot survey, two question items were deleted in order to attain high reliability (Cronbach alpha $=0.887$ ) and four question items were integrated into others in order to be consistent with the purpose of this present study.

On the 21 August 2005, the revised questionnaire consisting of 21 question items in Japanese was distributed online to the 174 e-learners, 72 in Group A and 102 in Group B. As in the pilot survey, a five-point, Likert-type response scale was employed. In total, 138 responses were collected over 10 days. 


\section{Development of instrument}

For this survey, the 21 question items were grouped into instructional and environmental categories. The group of ten instructional categories was defined as internal motivational categories, whilst that of eleven learning environmental categories was external in nature (William \& Burden, 1997, in Dornyei, 2001). The former group was identified by following four categories of the ARCS model, an acronym for these categories 'Attention', 'Relevance', 'Confidence' and 'Satisfaction' (Keller, 2001) (see Table 2).

Table 2: Questionnaire survey

\begin{tabular}{|c|c|c|c|}
\hline & Category & Subcategory & Likert question items \\
\hline \multirow{10}{*}{$\begin{array}{l}\text { Internal } \\
\text { motiva- } \\
\text { tional } \\
\text { categories }\end{array}$} & \multirow[t]{2}{*}{ Attention } & $\begin{array}{l}\text { Perceptual } \\
\text { arousal }\end{array}$ & $\begin{array}{l}\text { 1. Various learning tools such as lecture TV, } \\
\text { textbooks, BBS attract my attention. }\end{array}$ \\
\hline & & $\begin{array}{l}\text { Epistemic } \\
\text { curiosity }\end{array}$ & 2. I would like to study further by myself \\
\hline & \multirow[t]{3}{*}{ Relevance } & $\begin{array}{l}\text { Goal } \\
\text { orientation }\end{array}$ & $\begin{array}{l}\text { 3. I have my clear learning goal for each } \\
\text { course or this MBA program. }\end{array}$ \\
\hline & & Present worth & $\begin{array}{l}\text { 4. Knowledge learned here is appropriate to } \\
\text { my current situation. }\end{array}$ \\
\hline & & Experience & $\begin{array}{l}\text { 5. The course contents are generally familiar } \\
\text { to me. }\end{array}$ \\
\hline & \multirow[t]{2}{*}{ Confidence } & $\begin{array}{l}\text { Learning } \\
\text { requirements }\end{array}$ & $\begin{array}{l}\text { 6. I am sure I will be able to complete this } \\
\text { program. }\end{array}$ \\
\hline & & $\begin{array}{l}\text { Personal } \\
\text { control }\end{array}$ & $\begin{array}{l}\text { 7. It is easy for me to study here while } \\
\text { working. }\end{array}$ \\
\hline & \multirow[t]{3}{*}{ Satisfaction } & $\begin{array}{l}\text { Natural } \\
\text { consequences }\end{array}$ & $\begin{array}{l}\text { 8. I am sure I can use acquired knowledge in } \\
\text { a real setting. }\end{array}$ \\
\hline & & Equity & $\begin{array}{l}\text { 9. What I acquire here including course } \\
\text { grades satisfies me. }\end{array}$ \\
\hline & & $\begin{array}{l}\text { Positive } \\
\text { consequences }\end{array}$ & $\begin{array}{l}\text { 10. Learned knowledge (will) lead/s me to } \\
\text { better results in my life. }\end{array}$ \\
\hline \multirow{11}{*}{$\begin{array}{l}\text { External } \\
\text { motiva- } \\
\text { tional } \\
\text { category }\end{array}$} & \multicolumn{3}{|c|}{ 11. My family encourages my study. } \\
\hline & \multicolumn{3}{|c|}{ 12. My company helps me study here. } \\
\hline & \multicolumn{3}{|c|}{ 13. My colleagues in the company encourage my study. } \\
\hline & \multirow{2}{*}{\multicolumn{3}{|c|}{$\begin{array}{l}\text { 14. Time flexibility is helpful for my study. } \\
\text { 15. Place flexibility is helpful for my study. }\end{array}$}} \\
\hline & & & \\
\hline & \multicolumn{3}{|c|}{ 16. Virtual class (online chat) is helpful for my study. } \\
\hline & \multicolumn{3}{|c|}{ 17. I try to keep good relationship with peers. } \\
\hline & \multicolumn{3}{|c|}{ 18. I try to find a chance to meet peers face-to-face. } \\
\hline & \multicolumn{3}{|c|}{ 19. Group work helps my study and understanding. } \\
\hline & \multicolumn{3}{|c|}{ 20. Online interaction with teachers helps my study. } \\
\hline & \multicolumn{3}{|c|}{ ction with peers helps my study. } \\
\hline
\end{tabular}

The ARCS model is a method for improving the motivational appeal of instructional materials, widely applied for formative evaluation studies to provide suitable suggestions for instructional designers (Keller \& Suzuki, 
2004). This model is an expanded Expectancy-Value theory, a positive expectancy for success and the satisfaction of personal needs, into four motivational categories. Keller (2004) explains each category as follows. 'Attention' is a prerequisite condition for starting and maintaining the study, by stimulating perceptual and epistemic curiosity. 'Relevance' refers to learners' recognition that the instructional requirements are consistent with their goals, suitable for their learning styles, and linked to their past experiences. 'Relevance' also includes achievement, affiliation, and power motives. 'Confidence' is related to self efficacy, success experience, and attribution theory. 'Satisfaction' deals with sustaining motivation and performance by using extrinsic reinforcements including positive rewards and cognitive feedback, in ways that do not have a harmful effect on intrinsic motivation. This ARCS model was developed by synthesising various concepts and theories of human motivation into each simple category.

For this present study, the selective subcategories under the four categories of the ARCS model (Gagne et al, 2005) were applied to the identification of each question item. 'Attention' consists of perceptual arousal and epistemic curiosity, 'Relevance' includes goal orientation, present worth and experience, 'Confidence' is composed of learning requirements and personal control, and 'Satisfaction' refers to natural consequences, equity, and positive consequences.

\section{Analyses}

The Cronbach reliability coefficient alpha for the overall question items was 0.878, for the items in Group A, 0.751, and for Group B, 0.663. Factor analysis was used to test the relationship with the instrument adopted by the ARCS model and the external categories. Further, an independent $t$-test was examined to analyse comparisons in item levels between Group A and B. All of these analyses were done with SPSS (Statistical Package for the Social Sciences) Windows V. 11.5.

\section{Results}

\section{Factor analyses}

Both Group A and B were estimated using the principal factor method. The initial eigenvalues identified four factors in each group. The cumulative percentage of variance for the fourth factor in Group A was $58.13 \%$ and that of Group B was $55.01 \%$. After the Promax rotation (seven times for Group A and six times for Group B, until convergence was reached), factors which had loadings of 0.4 or higher on an only factor were selected. Loadings above the cutoff are in shaded cells in Table 3 (Group A) and 4 (Group B). Items deleted from Group A were five, the item No. 8, 16, 17, 18 
and 19. Items deleted from Group B were three, the item No. 1, 16 and 17. Subscale reliability alphas for all the factors were over 0.70 .

Table 3: Factor analysis for Group A

\begin{tabular}{|c|c|c|c|c|c|c|}
\hline & \multirow{2}{*}{ Category } & \multirow{2}{*}{$\begin{array}{l}\text { Question } \\
\text { item }\end{array}$} & \multicolumn{4}{|c|}{$\begin{array}{l}\text { FACTOR (Reliability } \\
\text { alpha) }\end{array}$} \\
\hline & & & \begin{tabular}{c|}
1 \\
$(0.762)$
\end{tabular} & $\begin{array}{c}2 \\
(0.799)\end{array}$ & $\begin{array}{c}3 \\
(0.838)\end{array}$ & $\begin{array}{c}4 \\
(0.880)\end{array}$ \\
\hline \multirow{10}{*}{$\begin{array}{l}\text { Internal } \\
\text { motiva- } \\
\text { tional } \\
\text { factors }\end{array}$} & \multirow[t]{2}{*}{ Attention } & $\begin{array}{l}\text { 1. Various learning tools such as } \\
\text { lecture TV, textbooks, BBS attract } \\
\text { my attention. }\end{array}$ & -0.111 & -0.011 & 0.067 & 0.799 \\
\hline & & $\begin{array}{l}\text { 2. I would like to study further by } \\
\text { myself. }\end{array}$ & 0.011 & -0.005 & 0.160 & 0.827 \\
\hline & \multirow[t]{3}{*}{$\begin{array}{l}\text { Releva- } \\
\text { nce }\end{array}$} & $\begin{array}{l}\text { 3. I have my clear learning goal for } \\
\text { each course or this MBA program. }\end{array}$ & 0.004 & 0.217 & 0.709 & 0.227 \\
\hline & & $\begin{array}{l}\text { 4. Knowledge learned here is app- } \\
\text { ropriate to my current situation. }\end{array}$ & 0.597 & -0.116 & 0.019 & 0.373 \\
\hline & & $\begin{array}{l}\text { 5. The course contents are } \\
\text { generally familiar to me. }\end{array}$ & 0.396 & -0.140 & 0.373 & 0.059 \\
\hline & \multirow[t]{2}{*}{$\begin{array}{l}\text { Confid- } \\
\text { ence }\end{array}$} & $\begin{array}{l}\text { 6. I am sure I will be able to } \\
\text { complete this program. }\end{array}$ & 0.139 & 0.363 & 0.328 & -0.420 \\
\hline & & $\begin{array}{l}\text { 7. It is easy for me to study here } \\
\text { while working. }\end{array}$ & 0.099 & 0.666 & 0.029 & -0.059 \\
\hline & \multirow[t]{3}{*}{$\begin{array}{l}\text { Satisfac- } \\
\text { tion }\end{array}$} & $\begin{array}{l}\text { 8. I am sure I can use acquired } \\
\text { knowledge in a real setting. }\end{array}$ & 0.370 & -0.201 & 0.180 & 0.340 \\
\hline & & $\begin{array}{l}\text { 9. What I acquire here inclu- } \\
\text { ding unit grades satisfy me. }\end{array}$ & 0.006 & 0.138 & 0.850 & 0.109 \\
\hline & & $\begin{array}{l}\text { 10. Learned knowledge (will) } \\
\text { lead/s me to better results in my } \\
\text { life. }\end{array}$ & -0.312 & -0.109 & 0.869 & -0.128 \\
\hline \multirow{11}{*}{$\begin{array}{l}\text { External } \\
\text { motiva- } \\
\text { tional } \\
\text { factors }\end{array}$} & \multicolumn{2}{|c|}{ 11. My family encourages my study. } & -0.045 & 0.551 & 0.170 & 0.014 \\
\hline & \multicolumn{2}{|c|}{ 12. My company helps me study here. } & 0.128 & 0.828 & -0.160 & 0.009 \\
\hline & \multicolumn{2}{|c|}{$\begin{array}{l}\text { 13. My colleagues in the company encourage } \\
\text { my study. }\end{array}$} & -0.166 & 0.824 & 0.035 & 0.038 \\
\hline & \multicolumn{2}{|c|}{ 14. Time flexibility is helpful for my study. } & 0.713 & 0.205 & 0.007 & -0.125 \\
\hline & \multicolumn{2}{|c|}{ 15. Place flexibility is helpful for my study. } & 0.763 & -0.024 & -0.086 & -0.060 \\
\hline & \multicolumn{2}{|c|}{$\begin{array}{l}\text { 16. Virtual class (online chat) is helpful for my } \\
\text { study. }\end{array}$} & 0.093 & 0.451 & -0.018 & 0.517 \\
\hline & \multicolumn{2}{|c|}{ 17. I try to keep good relationship with peers } & 0.169 & -0.106 & 0.331 & -0.299 \\
\hline & \multicolumn{2}{|c|}{$\begin{array}{l}\text { 18. I try to find a chance to meet peers face to } \\
\text { face. }\end{array}$} & 0.129 & -0.095 & 0.173 & 0.137 \\
\hline & \multicolumn{2}{|c|}{$\begin{array}{l}\text { 19. Group work helps my study and } \\
\text { understanding. }\end{array}$} & 0.311 & -0.125 & 0.283 & -0.333 \\
\hline & \multicolumn{2}{|c|}{$\begin{array}{l}\text { 20. Online interaction with teachers helps my } \\
\text { study. }\end{array}$} & 0.647 & 0.051 & -0.173 & -0.147 \\
\hline & \multicolumn{2}{|c|}{$\begin{array}{l}\text { 21. Online interaction with peers helps my } \\
\text { study. }\end{array}$} & 0.527 & 0.002 & 0.075 & -0.023 \\
\hline
\end{tabular}


Table 4: Factor analysis for Group B

\begin{tabular}{|c|c|c|c|c|c|c|}
\hline \multirow{4}{*}{\begin{tabular}{|l|} 
\\
Internal \\
motiva- \\
tional \\
categories
\end{tabular}} & \multirow[b]{2}{*}{ Category } & \multirow{2}{*}{$\begin{array}{l}\text { Question } \\
\text { item }\end{array}$} & \multicolumn{4}{|c|}{ FACTOR (reliability alpha) } \\
\hline & & & $\begin{array}{c}1 \\
(0.868)\end{array}$ & $\begin{array}{c}2 \\
(0.701)\end{array}$ & $\begin{array}{c}3 \\
(0.766)\end{array}$ & $\begin{array}{c}4 \\
(0.788)\end{array}$ \\
\hline & \multirow[t]{2}{*}{ Attention } & $\begin{array}{l}\text { 1. Various learning tools such } \\
\text { as lecture TV, textbooks, BBS } \\
\text { attract my attention. }\end{array}$ & 0.159 & 0.13 & -0.08 & -0.129 \\
\hline & & $\begin{array}{l}\text { 2. I would like to study further } \\
\text { by myself }\end{array}$ & 0.553 & 0.204 & 0.219 & 0.088 \\
\hline & \multirow[t]{3}{*}{$\begin{array}{l}\text { Releva- } \\
\text { nce }\end{array}$} & $\begin{array}{l}\text { 3. I have my clear learning } \\
\text { goal for each course or this } \\
\text { MBA program. }\end{array}$ & 0.534 & -0.209 & 0.234 & -0.282 \\
\hline & & $\begin{array}{l}\text { 4. Knowledge learned here is } \\
\text { appropriate to my current } \\
\text { situation. }\end{array}$ & 0.651 & -0.137 & -0.096 & -0.056 \\
\hline & & $\begin{array}{l}\text { 5. The course contents are } \\
\text { generally familiar to me. }\end{array}$ & 0.134 & 0.719 & 0.010 & 0.146 \\
\hline & \multirow[t]{2}{*}{$\begin{array}{l}\text { Confid- } \\
\text { ence }\end{array}$} & $\begin{array}{l}\text { 6. I am sure I will be able to } \\
\text { complete this program. }\end{array}$ & 0.322 & 0.551 & 0.008 & 0.119 \\
\hline & & $\begin{array}{l}\text { 7. It is easy for me to study } \\
\text { here while working. }\end{array}$ & 0.530 & 0.381 & -0.067 & 0.358 \\
\hline & \multirow[t]{3}{*}{$\begin{array}{l}\text { Satisfa- } \\
\text { ction }\end{array}$} & $\begin{array}{l}\text { 8. I am sure I can use acquired } \\
\text { knowledge in a real setting. }\end{array}$ & 0.576 & 0.173 & 0.103 & -0.026 \\
\hline & & $\begin{array}{l}\text { 9. What I acquire here incl- } \\
\text { uding unit grades satisfy me. }\end{array}$ & -0.001 & -0.052 & 0.759 & 0.185 \\
\hline & & $\begin{array}{l}\text { 10. Learned knowledge (will) } \\
\text { lead/s me to better results in } \\
\text { my life. }\end{array}$ & -0.189 & 0.217 & 0.819 & -0.086 \\
\hline \multirow{11}{*}{$\begin{array}{l}\text { External } \\
\text { motiva- } \\
\text { tional } \\
\text { categories }\end{array}$} & \multicolumn{2}{|c|}{ 11. My family encourages my study. } & -0.028 & -0.234 & 0.468 & 0.111 \\
\hline & \multicolumn{2}{|c|}{ 12. My company helps me study here. } & 0.216 & -0.896 & 0.068 & 0.301 \\
\hline & \multicolumn{2}{|c|}{$\begin{array}{l}\text { 13. My colleagues in the company } \\
\text { encourage my study. }\end{array}$} & 0.194 & -0.881 & -0.005 & 0.014 \\
\hline & \multicolumn{2}{|c|}{$\begin{array}{l}\text { 14. Time flexibility is helpful for my } \\
\text { study. }\end{array}$} & -0.108 & -0.017 & 0.205 & 0.804 \\
\hline & \multicolumn{2}{|c|}{$\begin{array}{l}\text { 15. Place flexibility is helpful for my } \\
\text { study. }\end{array}$} & -0.026 & -0.010 & -0.053 & 0.580 \\
\hline & \multicolumn{2}{|c|}{$\begin{array}{l}\text { 16. Virtual class (online chat) is helpful } \\
\text { for my study. }\end{array}$} & 0.290 & -0.163 & -0.200 & 0.037 \\
\hline & \multicolumn{2}{|c|}{$\begin{array}{l}\text { 17. I try to keep good relationship with } \\
\text { peers. }\end{array}$} & 0.187 & 0.090 & 0.186 & -0.016 \\
\hline & \multicolumn{2}{|c|}{$\begin{array}{l}\text { 18. I try to find a chance to meet peers } \\
\text { face-to-face. }\end{array}$} & 0.447 & 0.095 & -0.036 & -0.367 \\
\hline & \multicolumn{2}{|c|}{$\begin{array}{l}\text { 19. Group work helps my study and } \\
\text { understanding. }\end{array}$} & 0.794 & -0.229 & -0.085 & 0.070 \\
\hline & \multicolumn{2}{|c|}{$\begin{array}{l}\text { 20. Online interaction with teachers helps } \\
\text { my study. }\end{array}$} & 0.507 & 0.222 & -0.244 & -0.119 \\
\hline & \multicolumn{2}{|c|}{$\begin{array}{l}\text { 21. Online interaction with peers helps } \\
\text { my study. }\end{array}$} & 0.480 & -0.057 & 0.342 & -0.282 \\
\hline
\end{tabular}


Each factor of Group A was named as follows.

1. 'Expectation for e-learning success.' This grouping consists of the benefits of e-learning settings including time and place flexibilities and online interaction.

2. 'Supporters in individual learning situations.' This grouping refers to encouragement from e-learner's company and family.

3. 'Clear goal set by individual e-learners.' This grouping deals with individual goals set by each e-learner and individual satisfaction with outcomes.

4. 'Interest.' This grouping indicates perceptual and inquiry arousal in elearning settings.

Each factor of Group B was named as follows.

1. 'Interdependence.' This grouping deals with substantial learning through interaction.

2. 'Independence.' This grouping indicates individual goals, needs, and desires individual e-learner is pursuing.

3. 'Sharing the rewards with family.' This grouping is related to satisfaction with family encouragement.

4. 'Flexibility.' This grouping refers to e-learning flexibility.

Table 5 shows the t-test results of the Likert questions. All the values of the items in Group A were higher than those in Group A. The highest mean score was the item 'I have my clear learning goal for each unit or this MBA program' in both Group A and B. The lowest mean score in Group A was 'It is easy for me to study here while working', and that in Group B was 'My colleagues of the company encourage my study'. The highest $t$-value was seen in 'I try to find a chance to meet peers face to face', and the lowest $t$ value was seen in 'My colleagues of the company encourage my study'.

\section{Findings and discussion}

\section{Motivation factors between novice and successful e-learners}

Motivation of the novice e-learners was identified as the following four factors, 'Expectation for e-learning success,' 'Supporters in individual learning situations,' 'Clear goal set by individual e-learners,' and 'Interest.' That of the successful e-learners was the following four factors; 'Interdependence,' 'Independence,' 'Sharing the reward with family,' and 'Flexibility.' Focusing on the items differently identified between Group A and $B$, the main features of those factors will be discussed. 
Table 5: Differences between Group A and Group B (Question item level)

\begin{tabular}{|c|c|c|c|}
\hline No. Likert questions & Group(N) & Mean (SD) & $\mathrm{t}$-test \\
\hline \multirow{2}{*}{$\begin{array}{l}\text { 1. Various learning tools such as lecture TV, } \\
\text { textbooks, BBS attract my attention. }\end{array}$} & $\mathrm{A}(68)$ & $3.40(0.76)$ & \multirow[t]{2}{*}{$-5.735^{* *}$} \\
\hline & B (70) & $4.11(0.71)$ & \\
\hline \multirow[t]{2}{*}{ 2. I would like to study further by myself. } & A (68) & $3.31(0.89)$ & \multirow[t]{2}{*}{$-9.117^{* *}$} \\
\hline & B (70) & $4.53(0.68)$ & \\
\hline \multirow{2}{*}{$\begin{array}{l}\text { 3. I have my clear learning goal for each course or } \\
\text { this MBA program. }\end{array}$} & A (68) & $4.38(0.62)$ & \multirow[t]{2}{*}{$-4.856^{* *}$} \\
\hline & B (70) & $4.81(0.39)$ & \\
\hline \multirow{2}{*}{$\begin{array}{l}\text { 4. Knowledge learned here is appropriate to my } \\
\text { current situation. }\end{array}$} & A (68) & $3.54(0.70)$ & \multirow[t]{2}{*}{$-5.127^{* *}$} \\
\hline & B (70) & $4.19(0.77)$ & \\
\hline \multirow[t]{2}{*}{ 5. The course contents are generally familiar to me. } & A (68) & $3.88(0.87)$ & \multirow[t]{2}{*}{$-2.544^{*}$} \\
\hline & B (70) & $4.20(0.55)$ & \\
\hline \multirow{2}{*}{$\begin{array}{l}\text { 6. I am sure I will be able to complete this } \\
\text { program. }\end{array}$} & A (68) & $2.79(0.87)$ & \multirow[t]{2}{*}{$-12.693^{* *}$} \\
\hline & B (70) & $4.31(0.47)$ & \\
\hline \multirow[t]{2}{*}{ 7. It is easy for me to study here while working. } & A (68) & $2.62(1.12)$ & \multirow[t]{2}{*}{$-11.689^{* *}$} \\
\hline & B (70) & $4.41(0.60)$ & \\
\hline \multirow{2}{*}{$\begin{array}{l}\text { 8. I am sure I can use acquired knowledge in a real } \\
\text { setting. }\end{array}$} & A (68) & $3.88(0.78)$ & \multirow[t]{2}{*}{$-3.640^{* *}$} \\
\hline & B (70) & $4.33(0.65)$ & \\
\hline \multirow{2}{*}{$\begin{array}{l}\text { 9. What I acquire here including course grades } \\
\text { satisfies me. }\end{array}$} & A (68) & $4.32(0.80)$ & \multirow[t]{2}{*}{-0.398} \\
\hline & B (70) & $4.37(0.59)$ & \\
\hline \multirow{2}{*}{$\begin{array}{l}\text { 10. Learned knowledge (will) lead/s me to better } \\
\text { results in my life. }\end{array}$} & A (68) & $4.26(0.73)$ & \multirow[t]{2}{*}{-0.277} \\
\hline & B (70) & $4.30(0.77)$ & \\
\hline \multirow[t]{2}{*}{ 11. My family encourages my study. } & A (68) & $3.51(0.89)$ & \multirow[t]{2}{*}{$-3.356^{* *}$} \\
\hline & $\mathrm{B}(70)$ & $4.01(0.86)$ & \\
\hline \multirow[t]{2}{*}{ 12. My company helps me study here. } & A (68) & $3.10(1.26)$ & \multirow[t]{2}{*}{-0.579} \\
\hline & B (70) & $3.23(1.29)$ & \\
\hline \multirow{2}{*}{$\begin{array}{l}\text { 13. My colleagues in the company encourage my } \\
\text { study. }\end{array}$} & A (68) & $3.13(0.96)$ & \multirow[t]{2}{*}{-0.222} \\
\hline & $\mathrm{B}(70)$ & $3.17(1.10)$ & \\
\hline 14. Time flexibility is helpful for my study. & A (68) & $4.13(0.71)$ & $-4.571^{* *}$ \\
\hline & $\mathrm{B}(70)$ & $4.67(0.68)$ & \\
\hline 15. Place flexibility is helpful for my study. & A (68) & $4.04(0.74)$ & $-3.965^{* *}$ \\
\hline & $\mathrm{B}(70)$ & $4.54(0.74)$ & \\
\hline 16. Virtual class (online chat) is helpful for my & A (68) & $3.32(0.70)$ & $-10.473^{* *}$ \\
\hline study. & B (70) & $4.60(0.73)$ & \\
\hline 17. I try to keep good relationship with peers. & A (68) & $3.01(0.78)$ & $-11.521^{* *}$ \\
\hline & B (70) & $4.49(0.72)$ & \\
\hline 18. I try to find a chance to meet peers face to face. & A (68) & $3.10(0.76)$ & $-13.513^{* *}$ \\
\hline & B (70) & $4.66(0.59)$ & \\
\hline 19. Group work helps my study and & A (68) & $2.99(0.74)$ & $-11.372^{* *}$ \\
\hline understanding. & $\mathrm{B}(70)$ & $4.31(0.63)$ & \\
\hline 20. Online interaction with teachers helps my & A (68) & $3.24(0.76)$ & $-6.793^{* *}$ \\
\hline study. & $\mathrm{B}(70)$ & $4.01(0.58)$ & \\
\hline 21. Online interaction with peers helps my study. & A (68) & $3.66(0.87)$ & $-7.065^{* *}$ \\
\hline & B (70) & $4.56(0.58)$ & \\
\hline
\end{tabular}

Note. Group A: novice e-learners, Group B: successful e-learners

${ }^{*} p<0.05$ (2-tailed) ${ }^{* *} p<0.01$ level (2-tailed) 
Learning goals

Almost all the e-learners decided to enter this program with a clear goal for their future. Most respondents said that the purpose to enter this program was not to just earn the degree itself, but to acquire knowledge and skills to improve their job related performance, or to establish their own company. In general, the popularity of an MBA degree itself has been decreasing in Japan as well as in the US (Nikkei, 2005). It seems partly because an MBA degree is not a prescript certificate like other professional areas such as accounting or law. They rather want to acquire knowledge, and skills to pursue successful careers in business.

Interestingly, the question item 'I have my clear learning goal for each unit of this MBA program' was categorised into a different grouping between Group A and B. It seems that the novice e-learners set individual goals, whilst the successful e-learners enhance their needs, values and goals by interdependence (Johnson \& Johnson, 2004). However, the constructs of this interdependence did not indicate that each e-learner cares about maintaining harmonious relationships with peers. A similar inclination was also seen in terms of the relation between e-learner and company.

\section{E-learner's company and family}

The categorisation of the question items related to e-learner's company were also different between Group A and B. The factors related to each elearner's company can be a trigger to start the program, but it seems that they gradually develop innovative ideas which may not necessarily be related well with their current positions at their companies. In contrast, family members usually exist where e-learners study at home, partly because of housing conditions in Tokyo. Several successful e-learners said, "Because my learning behaviour influences my children, I have to study hard." Also, this result is consistent with the latest survey on the Japanese national character by the Research Committee of ISM (2005). This reveals that Japanese attitudes are changing. Nowadays, Japanese prioritise family life highly and have a tendency to value private life and avoid various social affairs including their company's problems. This point will be discussed later, but family presence cannot be disregarded for their motivation.

\section{Flexibility}

The question items related to flexibility were categorised differently. Given the fact that the e-learners of Group A had studied for fewer than two months, time and place flexibility might be regarded as just part of the benefits of e-learning, as online interaction might be. In fact, people who decide to enter this program are busy business persons, in particular at 
their working prime. However, successful e-learners realise that flexibility should be a benefit, but at the same time, might cause procrastination. As the process of learning continues, e-learners are able to increase their learning and motivation strategies. In due course, individual online learning schedules including time and place seem to become fixed and not directly influenced by other factors or problems. Our learning management system (Blackboard) records indicated that individual online times become gradually stable; quite early morning or late at night, every day. It appears to form a habit. Japanese tend to endure hardship (Singleton, 1995), and that characteristic may partly help adult e-learners motivation.

\section{Japanese general characteristics related to motivation}

Not only were the values of the question items in Group B much higher than those in Group A, but also the interaction in Group B was significantly correlated with the internal motivational categories. In particular, group work helped each e-learner to learn and to enhance motivation. There are three possible reasons in terms of Japanese general characteristics. First, the research finding of Hayamizu (1998) is compatible. Hayamizu reported that affiliation motivation helps achievement motivation in Japanese society, on the basis of Japan's collectivism. In fact, most e-learners said that they felt responsibility when working with group members, and worked harder than when working alone.

Second, in general Japanese feel uneasy about asking questions of teachers (Matsumoto, 1999), and are sensitive to teachers' reactions. Much literature points to the relation between teaching presence and perceived learning, and indicates that interaction with teachers had a much larger effect on satisfaction and perceived learning than interaction with peers (e.g. Pawain et al., 2003; Picciano, 2002; Swan, 2001). However, Biesebach-Lucas (2005) compared email messages from American students to professors and from students in Japan, Korea, Taiwan and Thailand to professors, and found that American students were more active than other students.

Further, Japanese society encompasses high context cultures (Doi, 2001). The e-learners in this program who have worked at the same company for more than 10 years have had relatively little opportunity to interact with people in other business fields. Lack of mental health care systems in general in Japanese business society might also increase the attractiveness of online interaction. It has been unusual to meet a public counsellor or mental supporter (Wada, 2004), but it seems that adult business persons seek those who listen to their business problems or provide some advice under a relaxed mood. The e-learners said they appreciate this interdisciplinary online environment and would like to keep this online network even after they graduate. Although online communication 
requires quick clear statements with its lack of nonverbal communication cues, interaction with peers online under less pressure may provide practice in sharing or converting tacit knowledge. With peers functioning as models for each other, professors have a particular role in providing appropriate tension for the online class. For example, during the first week of a unit, a professor explicitly and frequently appears online as a trigger, but after that week, assumes a more reserved presence, in order to give best scope for peer to peer interaction. Depending on the progress of these interactions, the professor may intervene with effective comments, such as 'That's a good idea, but try to find much better one,' or 'Why not more deeply examine that case?' The way to provide comments and the comments themselves may differ between professors and nationalities, but e-learners offer their opinions on the premise that their professor is always online. Japanese e-learners might derive their latent insight from those peer to peer active interactions.

The third reason is related to e-learner confidence. In general, adult learners often face various disrupting factors such as family, job and financial issues beyond their control. Adults also tend to judge changes in their intellectual abilities mainly in terms of their memory performance and in their physical capacities. In addition, Scholz et al.'s (2002) research on cross cultural self efficacy found that Japan marked the lowest among 25 countries, and reasoned that self efficacy may be valued lower in collectivistic cultures than in individualistic cultures. Interaction with peers may be necessary for Japanese to raise self confidence

Thus, Japan's collectivism assumes online group work to be valuable for motivation. However, this present study found results which are in disaccord with general collectivism. That is, both 'interdependence' and 'independence', existed in the successful e-learners. Otherwise, this 'independence' might not be equal to independence as it is depicted in the literature. This study cannot reach any conclusion, but speculative reasons might be derived from this unique program's contents that include global business issues and encompass Japanese and English, from an e-learning setting that expects independent study, from Japanese characteristics changing (Hayamizu, 2006), or from uniqueness of the adult learners or elearners enrolled in this program. Further research on this issue will be expected.

\section{Enhancement of and interference with e-learners' motivation}

From this study's observations, interviews and questionnaires, three major elements that have enhanced the e-learners' motivation in this MBA program will be discussed. First, face to face interaction seems necessary. Many successful e-learners admitted it to be powerful. Research findings 
have also suggested that face to face communication should be regarded as important in motivation (e.g. Johnson \& Johnson, 2004). The second element is interaction with this program's administrators at both Bond University and BBT Inc., in both languages, Japanese and English. This interaction makes e-learners involved with organisation of this program. By continuously publicising online their feelings, thoughts and desires, and partly immersing themselves in Australian culture, the e-learners may not only strengthen motivation but also cultivate their powers of self expression and creativity.

\section{Conclusion}

The purpose of this case study was to examine various motivation factors for working adult Japanese e-learners. The data were gathered from observations over an extended period of time since 2001, and interviews and questionnaires conducted in 2005. Motivation factors of Japanese elearners were similar to those found in other countries. The most remarkable feature, however, would be that Japanese e-learners' motivation is highly influenced by collaborative interaction, particularly in group activities. Interaction in e-learning settings goes beyond social activities and the simple exchange of information. Vygotsky (1978) identified that learners' cognitive strategy developments and verbalisations of their actions are directly influenced by their interactions with more capable members of their culture. Adult learners have individually unique experiences and backgrounds, which will make it easier to create optimum interaction with peers.

The results of this study cannot be generalised to other e-learning contexts in Japan due to the limited number of participants and question items, their unique learning situation, and the nature of this study as a case study. Further research will be needed to provide more definitive conclusions in the field of motivation of adult e-learners in Japan. In particular, we need to investigate what motivational factors influence adult Japanese e-learners under different learning situations, how individual cognitive style, characteristics, past learning experiences and backgrounds affect motivation, and how assimilation or acculturation processes and social presence in online learning environments influence motivation.

\section{Acknowledgement}

The author would like to thank Kazushi Wakabayashi of BBT Inc. and the e-learners of the Bond-BBT MBA program who participated in this study. 


\section{References}

Allen, M., Mabry, E., Mattrey, M., Bourhis, J., Titsworth, S. \& Mattrey, M. (2004). Evaluating the effectiveness of distance-learning: A comparison using metaanalysis. Journal of Communication, 54(3), 402-420.

Becker, D. (2002). Online course design: An MBA course example. In G. Richards (Ed), Proceedings of World Conference on E-Learning in Corporate, Government, Healthcare, and Higher Education 2002 (pp. 1175-1178). Chesapeake, VA: AACE.

Biesenback-Lucas, S. (2005). Communication topics and strategies in e-mail consultation: Comparison between American and international university students. Language Learning and Technology, 9(2), 24-46. [verified 12 Aug 2006] http:/ /llt.msu.edu/vol9num2/biesenbachlucas/default.html

Bird, J. \& Morgan, C. (2003). Adults contemplating university study at a distance: Issues, themes and concerns. International Review of Research in Open and Distance Learning, 4(1). [verified 8 Aug 2006] http:/ /www.irrodl.org/index.php/irrodl/article/view/130/210

Chou, S. W. \& Liu, C. H. (2005). Learning effectiveness in web-based technologymediated virtual learning environment. Proceedings of the 38th Hawaii International Conference on System Sciences. [verified 8 Aug 2006] http://csd12.computer.org/comp// proceedings/hicss/2005/2268/01/22680003a.pdf

Dornyei, Z. (2001). Teaching and researching motivation. London. Pearson Education.

Doi, T. (2001). Amae no kozo - sinso ban(in Japanese) [The anatomy of dependence new edition]. Tokyo. Kobundo Ltd.

Gagne, R. M., Wager, W. W., Golas, K. C. \& Keller, J. M. (2005). Principles of Instructional Design. Fifth edition (pp. 113-117). Thomson.

Gibbs, A. (1997). Social research update. [viewed 3 July 2006] http:/ / www.soc.surrey.ac.uk/sru/SRU19.html

Hayamizu, T. (1998). Jikokeisei no shinri-jiritsuteki doki zuke (in Japanese) [Psychology of self-awareness - autonomous motivation]. Tokyo. Kaneko shogo.

Hayamizu, T. (2006). Tanin wo mikudasu wakamonotachi (in Japanese) [Adolescents undervaluing others]. Tokyo. Kodan sha.

ISM (The Institute of Statistical Mathematics) (2005). A Statistical Research on the Japanese National Character: General Trends in Attitude over the Past Fifty Years (in Japanese). Proceeding of the Institute of Statistical Mathematics. 53(1). 3-33. [viewed 19 Aug 2006] http://www.ism.ac.jp/editsec/toukei/pdf/53-1-003.pdf

Johnson, D. W. \& Johnson, R. T. (2004). Cooperation and the use of technology. In D. H. Jonassen (Ed), Handbook of research on educational communications and technology. (pp. 785-812). London, Lawrence Erlbaum Associates.

Keller, J. M. (2001). Development and use of the ARCS model of motivational design. In D. P Ely \& T. Plomp (Eds), Classic Writings on Instructional Technology Volume 2 (pp. 223-238). Englewood, Colorado. Libraries Unlimited, Inc. Reprinted from Journal of Instructional Development, 10(3), 2-10. 
Keller, J. M. (2004). A predictive model of motivation, volition, and multimedia learning. A paper presented at the International Symposium and Conference on Educational Media in Schools, Kansai University, Osaka, 3-4 August (Proceedings, 9-19).

Keller, J. M. \& Suzuki, K. (2004). Learner motivation and e-learning design: A multinationally validated process. Journal of Educational Media, 29(3), 229-239.

Kim, K.-J., Liu, X., Lee, S., Bonk, C.J., Magjuka, R.J., Liu, S., Zhai, M., Su, B. and Wise, A. (2004). Online facilitation and motivation in online MBA courses. Association for Educational Communications and Technology. Chicago, IL, 1923 October. [verified 14 Aug 2006] ERIC \# ED485054. http:/ / eric.ed.gov/ ERICWebPortal/contentdelivery/servlet/ERICServlet?accno=ED485054

Li, Q. (2004). Knowledge building community: Keys for using online forums. TechTrends, 48(4), 24-28.

Lim, D. H. (2004). Cross cultural differences in online learning motivation. Educational Media International, 41(2), 163-175.

Luca, J. \& McLoughlin, C. (2004). Using online forums to support a community of learning. World Conference on Educational Multimedia, Hypermedia and Telecommunications, 2004(1), 1468-1474.

Matsumoto, S. (1999). Communication and education (in Japanese). Communication Educational Forum 99; komunikeishon kyouiku no genjo to kadai (pp. 1-6). Tokai University.

MEXT (Ministry of Education, Culture, Sports, Science and Technology) (2006). Gakkou kihon chosa tokuhou (in Japanese) [School datum survey] [viewed 20 Aug 2006] http:/ / www.mext.go.jp/b_menu/toukei/001/06080115/001.htm\#002

National Center for Education Statistics (NCES) (2005). A Profile of Participation in Distance Education: 2002-2003, U.S. Department of Education. [verified 8 Aug 2005] http:/ / nces.ed.gov / pubsearch/pubsinfo.asp?pubid=2005010

Nikkei (2005). Bei business school shigansha, sannen renzoku MBA ninkini kageri (newspaper in Japanese) [Continuous decrease of the number of US MBA school applicants for three years]. 31 August.

NIME (National Institute of Multimedia Education) (2006). The survey on elearning at universities. (in Japanese) http://www.nime.ac.jp/reports/001/ [verified 4 July 2006]

Pawan, F., Paulus, T. M., Yalcin, S. \& Chang, C. (2003). Online-learning: Pattern of engagement and interaction among in-service teachers. Language Learning and Technology, 7(3), 119-140. http://llt.msu.edu/vol7num3/pawan/default.html

Picciano, A. G. (2002). Beyond student perceptions: Issues of interaction, presence, and performance in an online course. Journal of Asynchronous Learning Networks, 6(1), 21-40. http://www.sloan-c.org/publications/jaln/v6n1/v6n1_picciano.asp

Pintrich, P. R. \& Schunk, D. H. (2002). Motivation in education; Theory, research, and applications, 2nd. edition. Upper Saddle River, NJ Merrill Prentice Hall. 
Scholz, U., Gutiérrez-Doña, B., Sud, S. \& Schwarzer, R. (2002). Is perceived selfefficacy a universal construct? Psychometric findings from 25 countries. European Journal of Psychological Assessment, 18(3), 242-251. [verified 8 Aug 2006] http:/ / userpage.fu-berlin.de/ health/materials/gse_scholz2002.pdf

Singleton, J. (1995). Gambaru: A Japanese cultural theory of learning. In J.J. Shields Jr. (Ed.), Japanese schooling: Patterns of socialization, equality, and political control (pp. 8-15). University Park: Pennsylvania State University Press. [verified 8 Aug 2006] http:// www.japansociety.org/journey/images/indepth/ACF302A.pdf

Sitzmann, T. \& Wisher, R. (2005). The effectiveness of web-based training compared to classroom instruction: A meta-analysis. In S. Carliner \& B. Sugrue (Eds), Linking people-learning and performance: ASTD 2005 Research-to-practice conference proceedings (pp. 196-202). [verified 8 Aug 2006] http:/ / www.astd.org/NR/rdonlyres/462D84C4-4077-4242-84DD8C08BF236599/7113/R2P_Proceedings_v7.pdf

Scheuermann, M. (2003). Leveraging adult student value in the e-learning environment - a pedagogical shift. In C. Crawford et al. (Eds), Proceedings of Society for Information Technology and Teacher Education International Conference 2003 (pp. 2564-2566). Chesapeake, VA: AACE.

Stephen, J. (2003). A review of research and practice in e-learning in the work-place and proposals for its effective use. Paper presented at the Annual Meeting of the American Educational Research Association. 83th, Chicago, IL, 21-25 April.

Swan, K. (2001). Virtual interaction: Design factors affecting student satisfaction and perceived learning in asynchronous online course. Distance Education, 22(2), 306331.

TOEFL (Test of English as a Foreign Language) (undated). http: / www.ets.org/ portal/site/ets/menuitem.fab2360b1645a1de9b3a0779f1751509/?vgnextoid= 69c0197a484f4010VgnVCM10000022f95190RCRD

Vygotsky, L. S. (1987). Mind in society: The development of higher mental process. Cambridge, MA: Harvard University Press.

Yoshida, A. \& Taguchi, M. (2005). Mosakusareru e raningu (in Japanese) [Groping for e-learning]. Tokyo. Toshindo Publishing.

Wada, H. (2004). The psychology of team (in Japanese). Diamond Harvard Business Review. December, 2004, 35-47.

Hisayo Kikuchi is a part-time lecturer at Nihon University College of International Relations, 2-31-145 Bunkyou-cho, Mishima-shi, Sizuoka. http://www.ir.nihon-u.ac.jp/english/index.html

Previously she was a manager and coordinator for the Bond-BBT MBA program of Business Breakthrough Inc., 2-7 Gobancho Chiyoda-ku Tokyo. http:/ / www.bbt757.com/eng/ Email: hisayo@t07.itscom.net 